\title{
UAV による外来水生植物の生育状況の把握
}

\author{
津口 雅彦* ·福富直* - 望月貫一郎*
}

\section{1.はじめに}

オオバナミズキンバイ，十ガエツルノゲイトウ等の 侵略的外来水生植物（以下，外来水生植物）は，外来 生物法で「特定外来生物」に指定されており, 琵琶湖 や内湖，河川等に侵入し，広範囲にわたる大規模な繁 茂が確認されている。

これらの外来水生植物は, 広大な湖面を覆うほどの増 殖力を持ち, 生態系や漁業等への深刻な影響が懸念さ れている。地元の自治体でも大規模駆除等を継続的に 実施しているが, 根絶には至っていないのが現状である。

ここでは, UAV (無人飛行機) で撮影した空中写真 及び 5 波長によるマルチスペクトルカメラで撮影した デー夕を用いた外来水生植物の発生及び生育状況の把 握事例を紹介する。

\section{2. データ取得方法}

UAV（DJI 製 M600）を用いた撮影は，2017年 5 月 12 日，2017年 6 月 6 日の 2 時期に実施した。使用した

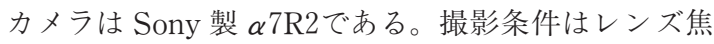
点距離 $35 \mathrm{~mm}$, 画素数 36 ×ガピクセル, 撮影高度は約 $110 \mathrm{~m}$ と $75 \mathrm{~m}$, 地上解像度は約 $1.5 \mathrm{~cm}$ と $1.0 \mathrm{~cm}$, オー バーラップ $80 \%$ サイドラップ $30 \%$ である。また，外来 水生植物の生育状況を確認するために, MicaSense 製 マルチスペクトルカメラ RedEdge を用いて, 撮影高

表 1 マルチスペクトルカメラ RedEdge のスペクトル特性

\begin{tabular}{ccc}
\hline \multicolumn{1}{c}{ BAND } & 波長 & 帯域幅 \\
\hline 1 : 青 & $475 \mathrm{~nm}$ & $20 \mathrm{~nm}$ \\
\hline $2:$ 緑 & $560 \mathrm{~nm}$ & $20 \mathrm{~nm}$ \\
\hline $3:$ 赤 & $668 \mathrm{~nm}$ & $10 \mathrm{~nm}$ \\
\hline $4:$ レッドエッジ & $717 \mathrm{~nm}$ & $10 \mathrm{~nm}$ \\
\hline 5 : 近赤外 & $840 \mathrm{~nm}$ & $40 \mathrm{~nm}$ \\
\hline
\end{tabular}

*株式会社パスコ

「写真測量とリモートセンシング」VOL. 57, NO. 2, 2018
度 $120 \mathrm{~m}$, 地上解像度 $8.1 \mathrm{~cm}$ で撮影した。表 1 に, この カメラのスペクトル特性を示す。

さらに, Agisoft 社製 PhotoScan を用いて, それぞ れの撮影した写真の 2 時期のオルソ処理を行った。

\section{3 . 外来水生植物の生育状況確認について}

図 1 (a)に, 琵琶湖西岸地区の2017年 5 月 12 日の外来 水生植物の生育範囲の全299枚の撮影写真によるオル ソ写真を示す。図 1 (b)に, 同地区の 2017 年 6 月 6 日の 外来水生植物の生育範囲が拡大した状況を示す。撮影 条件は2017年 5 月12日と同様であり, これら約300枚を 用いたオルソ写真である。困 1 (c)は, 図 1 (a)及び図 1 (b)の外来水生植物の生育範囲を独自の領域分割手法ソ フトを用いて自動抽出した結果である。外来水生植物 の生育面積は $4,912 \mathrm{~m}^{2}$ から $5,651 \mathrm{~m}^{2}$ となり, 26 日間で生 育面積は約 $15 \%$ 拡大したこととなる。

図 2 はUAV 搭載のマルチスペクトルカメラで シャッター数608回, 5 波長マルチスペクトル画像で 3,040枚を空撮したデータの各 5 つのスペクトル画像 を色表示して，図1の一部を拡大した図である。

図 2 (a), 図 2 (b), 図 2 (c)では, 外来水生植物を含めた 植物は, 同様な色合いで表示されている。そのため, 他 の植物と外来水生植物を区別することができない。し かし, 図 2 (d)では, 外来水生植物を赤と緑の色合成とし て黄色系の色合いで表示しているため，他の植物と区 別して認識できる。この理由は, 外来水生植物のレッド エッジ波長帯の反射率は, 近赤外の反射率と同程度以下 であるためである。反対に, 外来水生植物以外の植生の レッドエッジ波長帯の反射率は，近赤外の反射率より 大きいため, 黄緑色から緑色として表示される。この ことから, 外来水生植物の生育域を知ることができる。

\section{4.おわりに}

継続的な観測は, 外来水生植物の予測, 計画的・迅 速かつ効果的な駆除するための方策検討に寄与でき る。 


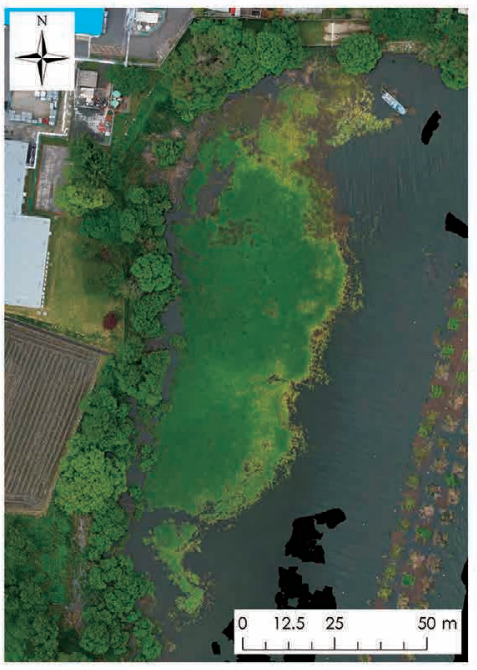

(a) オルソ写真

(2017年 5 月 12 日撮影)

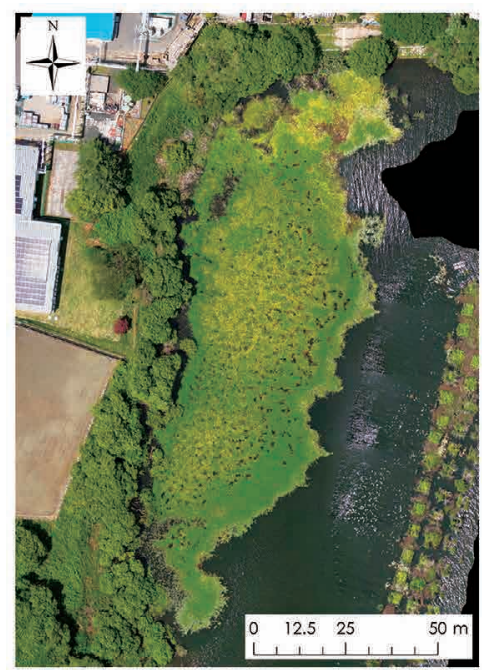

(b) オルソ写真

(2017年 6 月 6 日撮影)

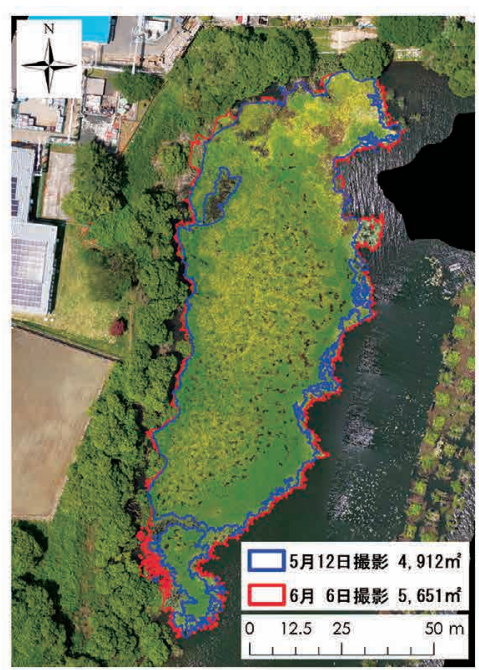

(c) 外来水生植物の生育拡大範囲図 ( 2 時期の差分結果)

図 12 時期のオルソ写真と外来水生植物の拡大

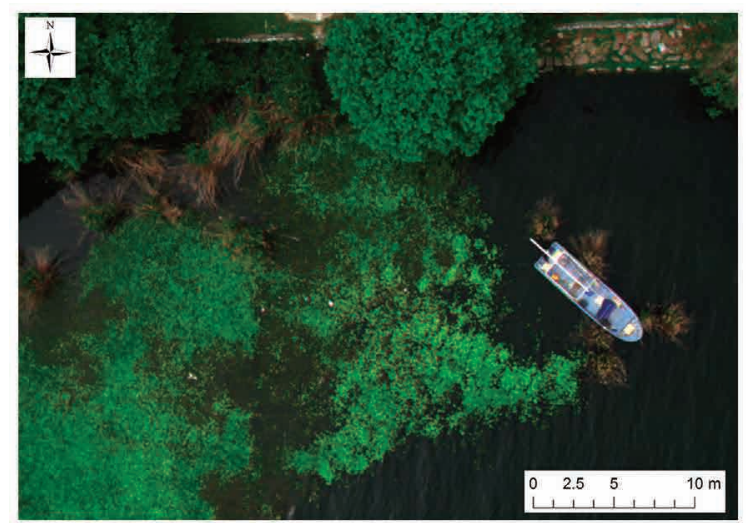

(a) $\mathrm{R}: \mathrm{G}: \mathrm{B}=3: 2: 1$ (赤：緑：青)

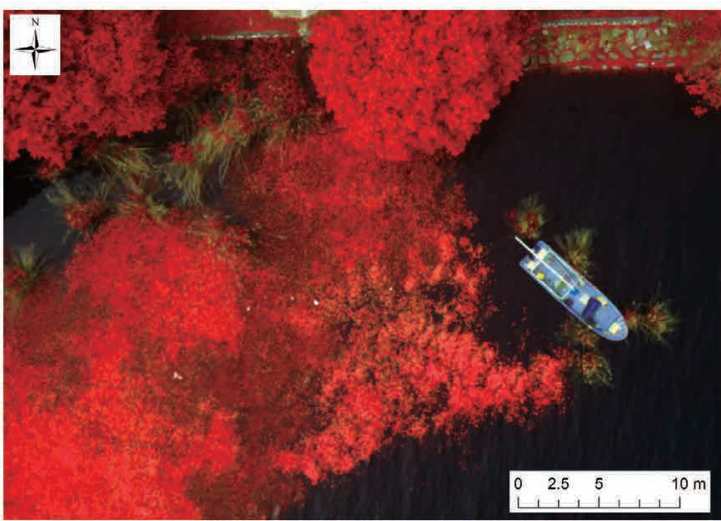

(c) $\mathrm{R}: \mathrm{G}: \mathrm{B}=5: 3: 1$ (近赤外: 赤: 青)

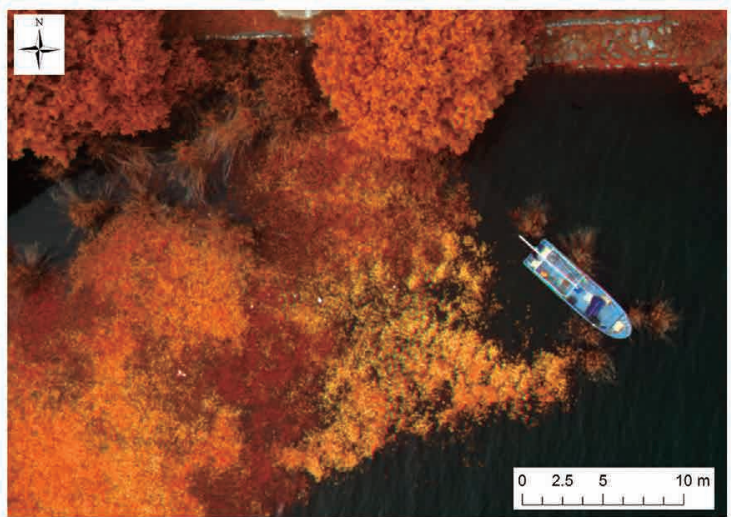

(b) $\mathrm{R}: \mathrm{G}: \mathrm{B}=5: 2: 1$ (近赤外：緑：青）

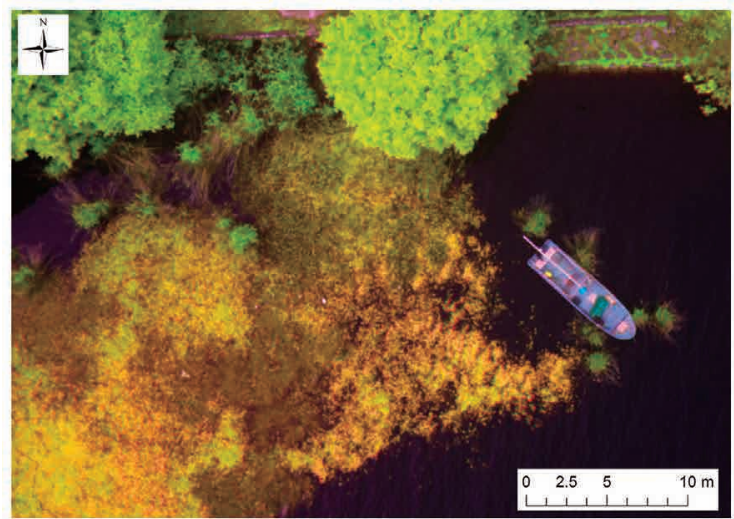

(d) $\mathrm{R}: \mathrm{G}: \mathrm{B}=5: 4: 1$ (近赤外：レッドエッジ：青)

図 2 マルチスペクトルカメラ画像（2017年 5 月12日撮影） 